\title{
Elementary Teachers' Thoughts about Distance Education and Learning 21st-Century Skills during COVID Pandemic
}

\author{
Amani K. H. Alghamdi \\ Imam Abdulrahman bin Faisal University, Dammam, Saudi Arabia \\ http://orcid.org/0000-0002-8500-0266 \\ Naimah Ahmad Al-Ghamdi \\ Imam Abdulrahman bin Faisal University, Dammam, Saudi Arabia \\ https://orcid.org/0000-0002-8851-0456
}

\begin{abstract}
There was a dearth of research documenting the Arab World's educational response to the COVID-19 pandemic. In particular, female Saudi elementary teachers' views on distance education during those unprecedented times were under-explored in the research literature. In the wake of the outbreak in Saudi Arabia, concerns have been raised about education disruption at the elementary school level and its impact on instilling and developing 21st-century skills. Conducted at a college of education in Saudi's Eastern Province, a qualitative exploratory study examined 20 Saudi postgraduate female students' written responses to a journal question concerning teaching elementary pupils online about the pandemic while $21^{\text {st }}$-century skills were being inculcated. A critical finding was that the participants expressed a sense of ample scope for personal and pedagogical transformation despite the enormity of the challenge. Suggestions for future research, pre-service, and in-service teacher training, and professional development were recommended around pedagogical adjustments for teaching elementary learners online

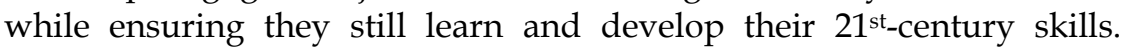

Keywords: COVID-19 pandemic; elementary students; distance learning;

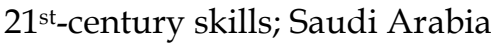

\section{Introduction}

The COVID-19 pandemic provided an opportunity to explore the subject of schooling in a new context. At present, attempts to contain the crisis encompass an adaptive response, which includes a transition to hybrid education (adopting a blend of both online and face-to-face learning strategies in both learning environments (Gagnon et al., 2020). There were concerns about whether such a new approach will strengthen learning and whether, or how, teaching will resume 
at the end of the de-escalation (Al-Roubaie \& Alaali, 2020; Khatun \& Saadat, 2020; Kovačević, 2020).

This exploratory study was based in the Kingdom of Saudi Arabia (KSA), which is transitioning to a knowledge-based and information-age economy necessitating students' learning of 21st-century skills. In addition, the main objective of this research was to disclose female Saudi elementary teachers' views on distance education during this unusual time. Such knowledge was beneficial and muchneeded. For clarification, these skills constituted critical thinking, creativity, collaboration, communication, several types of literacy (information, media, technology), flexibility, leadership, initiative, productivity, social skills, and local and global connections (Abualrob, 2019; Stauffer, 2020). The most useful pedagogical approach for teaching these skills was a student-centered, selfdirected, active learning and experiential learning pedagogy (Van Gompel, 2019).

Prior to the pandemic, the Saudi educational system was challenged because its teaching philosophy was detached from students' experiences and needs. A report on new models of education for the fourth industrial revolution argued that in both developing and developed countries, many educational systems still depend heavily on passively taught and memorized learning rather than interactive, critical, and self-directed methods (Basham et al., 2020; Jung, 2020; Sekiyama, 2020). Despite the strain caused by the pandemic, the Saudi school system was pushed to make significant changes. That is to say, any resultant school reconfiguration must respond and adapt to these complex times through approaches such as online or blended learning (Campa, 2020; Khatun \& Saadat, 2020; Voskoglou, 2020).Gagnon et al. (2020) defined blended learning as a synchronous online learning, which was used to enhance student learning between face-to-face sessions. Online instruction does NOT replace face-to-face time.

At the outbreak of the pandemic in spring 2020, virtually all nations opted for immediate school closure; about 1.6 billion pupils from elementary school to postsecondary level were prohibited from attending face-to-face classes. Instead, pupils were instructed to study online so that learning would not be disrupted because of the severe public health concerns. The COVID-19 crisis had emphasized the need to build both connected school communities and a stronger educational relationship between homes and schools. These unanticipated and/or not well-formed connections amount to a mix of positive and negative perceptions among students, teachers, and parents of the merits of distance learning (Burgess \& Sievertsen, 2020; Douglas et al., 2020).

Of relevance to this paper is that this prolonged crisis presented a remarkable challenge to schools and it was further exacerbated by the widespread lack of access to high-speed internet or interactive media. This digital divide among the student population affected their perceptions of their learning experiences during the COVID-19 pandemic (Esposito \& Principi, 2020; Lee, 2020; Viner et al., 2020; Wang et al., 2020). In particular, the number of Saudi Arabian (SA) young people and teens who are disadvantaged by a lack of technology was and still steadily 
growing (Alaboudi \& Alharbi, 2020; Almutairi et al., 2020; Alshammari, 2020). Anchored in this and other concerns of the pandemic, SA researchers should explore the experiences of elementary school children and their teachers in online learning during the pandemic. By doing so, resultant deeper understandings can be used to address attendant challenges so students can pursue their studies at home without being academically disadvantaged. This study focused herein on teachers who were responsible for ensuring that the learning environment run well (König et al., 2020; Rapanta et al., 2020).

\section{Significance of Research and Research Question}

The topic of teaching 21st-century skills in elementary school was underresearched (Van Gompel, 2019). This coupled with the fact that one third of Saudi citizens are aged from 0 to 14 (young learners) (Algaissi et al., 2020) and more than half of Saudi elementary teachers $(52.3 \%)$ are women (UNESCO Institute of Statistics, 2019). Such a fact led the researchers to serendipitously focus not only on soliciting opinions from formally trained Saudi female elementary teachers, but also on the notion of integrating 21st-century skills into the Saudi elementary curriculum during the pandemic. The study participants, therefore, included those who had returned to university on a part-time basis to obtain a master's degree in education.

It was thought that gainfully employed elementary teachers attending the graduate school for intellectual enrichment would provide a fertile avenue for soliciting authentic data, because they could draw on lived experiences before and during the pandemic. Hence, the research question guiding this inquiry was put forward:

RQ1: What are the thoughts of Saudi female postgraduates (who study elementary education) about how to develop and deliver a distance education lesson about COVID-19 the best while ensuring elementary students' 21st-century skills development?"

\section{Literature Review}

\subsection{Saudi Context and Global Pandemic Response}

Saudi Arabia is the largest country in the Arab world having a land mass of 21.5 million $\mathrm{km}^{2}$. Its population is approximately 35 million with the bulk aged 15 and 64 years. Those between 0 and 14 years accounted for $32.4 \%$ of the population with only $2.8 \%$ aged +65 years (Algaissi et al., 2020). Saudi Arabia also attracted many foreign workers with approximately 12 million overseas nationals that covered $37 \%$ of the country's residents. It is a key destination for investors, representatives of new industries and, increasingly, tourists. KSA is also of tremendous religious importance for the almost 2 billion Muslims around the world (Hackett \& McClendon, 2017). Each year, more than 2.5 million pilgrims visit the country, primarily the Makkah region, for both the five-day annual pilgrimage known as Hajj and the Islamic rite known as Umrah. With this influx of visitors, the KSA has been identified as a potential pandemic hotspot.

The country has a comprehensive medical system with free medical insurance available to all citizens and a network of hospitals and clinics, both public and 
private. Although there are currently 2.2 beds per 1,000 people (Alazmy et al., 2020; Samra et al., 2020), there are calls for significant structural changes in the healthcare sector to satisfy the growing needs of the country. Despite the aim of KSA to safeguard the well-being, protection, and welfare of both citizens and pilgrims, the spread of infectious diseases worldwide is always extremely dangerous (Al Saidi et al., 2020; Aldarhami et al., 2020); the implications of a pandemic could be particularly severe.

Bearing this in mind, on March 2, 2020, before the first case of COVID-19 was detected in Saudi Arabia (Alyami et al., 2020), the nation became one of the first countries to implement early and unparalleled security to deter or alleviate the spread of the disease on its soil. This included school closures and mandatory online distance education. Many studies around the world have documented school systems' responses to the COVID-19 crisis, including Armitage and Nellums (2020), Auger et al. (2020), Hilppö et al. (2020), Loima (2020), Poletti and Raballo (2020), and Sintema (2020) among others. Triggered by the novel Corona virus, school closure was imposed in different countries such as the US, Finland, and Sweden affecting school children's prospect of continuing their education and social life. However, few studies have been conducted within the Saudi context making this Arab-world study a valuable contribution to this bourgeoning knowledge base. In particular, Saudi female elementary teachers' outlooks towards teaching $21^{\text {st }}$-century skills online during the pandemic were obscure.

Regarding other jurisdictions, using a rapid systematic review of the literature, Viner et al. (2020) assessed the success of school suspensions, closures and management practices during Corona virus outbreaks including COVID-19. Per the latter, studies revealed two countries and a major city in the world: China, Hong Kong, and Korea that imposed school suspensions swiftly. However, school closures alone eliminated only $2 \%$ to $4 \%$ of virus transmissions relative to social distancing strategies (Bayrakdar \& Guveli, 2020). Viner et al. (2020) cautioned policymakers to be aware of misguided evidence urging them to give due consideration to combinations of social distancing measures and school closures. Stringent social distancing policies were implemented over lengthy stretches of time including measures to be taken within classrooms. According to Burgess and Sievertsen (2020), the COVID-19 pandemic is essentially a safety problem. Most countries have rightly decided to close schools, universities, and colleges. Politicians, however, faced a dilemma merely in closing schools to reduce contact and potentially save lives or leave them open allowing employees to do their jobs, and keeping the economy functioning and not disrupting learning. Keeping in mind that the latter required changes in the nations' education delivery systems.

\subsection{Importance of Elementary Education}

Indeed, the COVID-19 pandemic is creating an opportunity to explore the subject of schooling in a new context. The kneejerk reaction to minimize the learning continuation crisis was to impose distance learning or a hybrid version of learning (online and face-to-face) with negligible preparedness or readiness for all concerned parties. Perceptions and thoughts of both Saudi students and teachers about this policy decision must be explored giving the dearth of pertinent 
literature about this topic in the KSA. An investigation of this nature will reveal pedagogical implications for all levels of education with a special interest herein about the elementary curriculum provided to Saudi pupils aged six to 12 (from Grades One through Grade Six equivalent).

This age group matters because elementary students starting school now are future workers and leaders in a digital world that will demand new skills and new ways of thinking. Based on this, elementary educators must be able to teach elementary pupils effectively, in particular, in the face of a global crisis, such as a pandemic. As a matter of fact, elementary school education is considered as a ladder for child's future development. It shapes predispositions for lifelong learning and informs cognitive and social development of young generations. It is viewed as "an essential building block for a child's future success" (Walden University, 2020). Mead (2016) concurred that the quality and success of elementary education was a powerful predictor of a child's life outcomes. In the same line of thought, Mishrif and Alabduljabbar (2018) pointed out how important the primary and secondary education in Saudi Arabia are, because they are meant to help pupils and students adopt a positive attitude towards work and employment achieving the goals set in Vision 2030.

\subsection{Teaching 21st-Century Skills in Elementary School}

Regarding nation building, special attention is warranted for ensuring Saudi elementary students' learning of 21st-century skills is an effective one so that the future generations excel in a knowledge-based economy and in the modern Information Age. Young people comprised one third of the Saudi population (Algaissi et al., 2020) and will eventually assume the mantle of carrying the KSA into the future per Vision 2030, its most recent national development plan (KSA, 2016). Vision 2030 heavily depends on education to ensure its three goals: ambitious nation, thriving economy and vibrant society. All levels of education matter. In a powerful statement and as asserted by Abualrob (2019), "elementary school systems... should work to provide pupils with the dexterity they need to become engaged thinkers, resilient and resourceful learners, creative problem solvers and active members of their communities" (pp. 108-109).

Van Gompel (2019) has recently affirmed, however, that "research about effective pedagogical frameworks to support [teaching of $21^{\text {st }}$ century] skills in an elementary context is limited" (pp. 6). Yet, educators agreed that elementary students must be oriented to this skill set. It is never too young to start with this aspect of learning (Abualrob, 2019). To illustrate, Van Gompel (2019) explained that even for this age cohort, "creativity is required for critical thought [and] oral communication and collaborative skills are important together in order for [elementary] students to express thought and share ideas" (p. 29).

Unfortunately, like many teachers around the world, Saudi elementary educators have experienced all sorts of difficulties in delivering online lessons to young learners during the pandemic. Despite Saudi schools usually offering teachers access to teaching resources, and access to the internet and information technology (IT) connection, challenges and disruptions occurred during online 
lesson delivery and lesson preparation training. With the prospect of national lockdowns and the eventual reopening of schools in several areas of the country, it is critically important to assess and evaluate the possible future of schooling and curricula delivery in the KSA. This study focused on Saudi elementary educators' attitudes about teaching elementary pupils via distance education during the pandemic while ensuring students' attainment of 21st-century skills.

Results from surveying the internet showed some educational websites for school

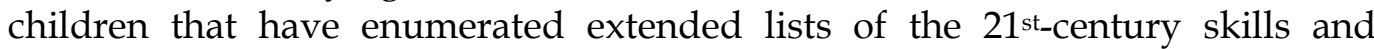
personal qualities. It emphasized that new generations need to learn and build at a young age those skills. Just to name a few, they included empathy, curiosity, adaptability, resilience, self-directed skills, collaboration/teamwork, active listening, information seeking, collaboration, lifelong learning, communication, creativity, and critical thinking (Nana, 2020; Simply Learning Tuition \& Consultancy, 2021).

\section{Method}

The study employed a qualitative exploratory research design (journaling). Exploratory studies tentatively probe or investigate a phenomenon especially when little is known about it in a given context. Rather than providing conclusive and final answers to the research questions and using smaller samples and structured answers, researchers strived to provide broad and initial understandings to lay the groundwork for more conclusive studies (Dudovskiy, 2016; McGregor, 2018).

\subsection{Sample Frame and Participants}

Education in Saudi Arabia is segregated. Female teachers are trained to teach female pupils, although this is slowly changing (Obaid, 2019). Using convenience sampling (i.e., the lead author was teaching the study participants as postgraduate students at an Eastern Province university), the final sample frame comprised of 20 female participants studying for their master's degree in education with 14 gainfully employed and six unemployed. Participants ranged in age between 26 to 45 years old. Most of them had a BA in Education or Arts, and a few had a BSc in Mathematics, Chemistry, Biology or Physics. Their teaching experience ranged between 6 and 11 years (averaging 8.5 years), and all worked at female schools. Within this sample frame, many participants were also parents with school-age children.

\subsection{Data Collection}

Data in the form of journal entries were collected in May2020. Participants were expected to offer their views and reflections about delivering an online class during the pandemic to elementary school pupils in the KSA. Specifically, the lead author emailed participants asking them to provide written answers and reflections on the following question: "If you were asked to prepare a distance learning-based educational lesson directed to the elementary stage on the dangers of the emerging Corona virus pandemic, how would you accomplish that?. They were further asked to write clear steps in line with teaching of 21st-century skills. 
Participants were required to return their responses via email within one week after receiving the given task. The lead author translated the journal entries from Arabic to English, and the co-authors checked the translation. Ethical considerations were observed, all the 20 participants provided signed consent (on submission of their assignments) for their journals to be used for research purposes only. One student in the class opted out of the study. All participants' names presented in this study were pseudonyms: $\mathrm{AB}, \mathrm{AL}, \mathrm{CH}, \mathrm{DM}, \mathrm{EH}, \mathrm{EM}, \mathrm{ET}$, FG, HD, HN, MN, MS, NJ1, NJ2, QS, RH, RW, SD, ZN, and ZR. In addition, the two analysts, both internal and external, who worked on the data set, did not have a direct involvement with the study participants to maintain the objectivity in handling the data.

\subsection{Data Analysis}

Upon reading the data set relative to the research question, the researchers decided to present the major findings using mostly extracts (longer passages or paragraphs) rather than shorter one-to-two sentence quotes (Kirklees Council, n.d.). The whole research team read the entire data set, identified extracts deemed especially powerful and insightful, by considering the outcomes of the content analysis. To clarify, participants' contributions were considered powerful if they covered innovative ideas that reflected how they would teach their students in such difficult times, and if they alluded to 21st-century skills. Decisions on which extracts to present were made "typically on a case by case basis" (Corden \& Sainsbury, 2006, p. 14), with assurances that their "selection reflected strong patterns in the data" (Lingard, 2019, p. 362).

The investigators consciously avoided presenting long extracts without analyzing, interpreting and discussing them (Anderson, 2010). Sometimes however, long extracts are exactly what is needed. The length of extracts staves off the need for readers' inference, because longer extracts can best express the participants' full idea (Lingard, 2019). To dissect the data set, a content analysis was also made. It revealed how the participants structured the content of their responses in these 10 categories: lesson preparation, digital set up, goals/objectives, student background knowledge, learning outcomes, lesson introduction, lesson development, consolidation, evaluation and conclusion. Erlingsson \& Brysiewicz $(2017,23)$ affirmed that "content analysis" is a reflective process "of working and re-working your data that reveals connections and relationships". 


\begin{tabular}{l|l|l|l|l|l|l|}
\multicolumn{2}{|c|}{ B } & \multicolumn{2}{c|}{ D } \\
\hline
\end{tabular}

Figure 1. Capturing the essence of the collected data

Figure 1 above showed the analyst-generated matrix that was used to capture and analyse the data teasing out important details about digital resources, teaching

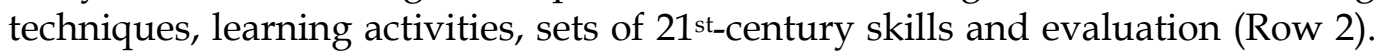
Indeed, all what have been contributed against the categories (Column A) were used in the content analysis and will be illustrated in the following section.

\section{Findings}

The content analysis of the qualitative data categories into 10 areas according to the requirements of the journal task, i.e., writing steps in teaching $21^{\text {st_century }}$ skills, were as follows: (1) lesson preparation, (2) digital set up, (3) goals/objectives, (4) student background knowledge, (5) learning outcomes, (6) lesson introduction, (7) lesson development, (8) consolidation, (9) evaluation and (10) conclusion. Table 1 illustrated what categories the participants had addressed. It also revealed some quantitative outcomes from the data analysis.

Table 1. Responses under different categories of the content analysis

\begin{tabular}{|c|c|c|c|c|c|c|c|c|c|c|c|c|}
\hline \multirow[b]{2}{*}{ Row } & \multirow{2}{*}{$\begin{array}{l}\text { Partici- } \\
\text { pants }\end{array}$} & \multicolumn{10}{|c|}{ Categories } & \multirow{2}{*}{$\begin{array}{c}\# \\
\text { Clear } \\
\text { Steps }\end{array}$} \\
\hline & & 1 & 2 & 3 & 4 & 5 & 6 & 7 & 8 & 9 & 10 & \\
\hline 1 & $\mathrm{AB}$ & Yes & Yes & $x$ & Yes & $x$ & Yes & Yes & $x$ & Yes & Yes & 8 \\
\hline 2 & $\mathrm{AL}$ & $x$ & $x$ & $x$ & $x$ & $x$ & $x$ & $x$ & $x$ & $x$ & $x$ & 0 \\
\hline 3 & $\mathrm{CH}$ & $x$ & Yes & $x$ & Yes & $x$ & Yes & Yes & $x$ & Yes & $x$ & 4 \\
\hline 4 & $\mathrm{DM}$ & Yes & Yes & $x$ & Yes & $x$ & $x$ & Yes & $x$ & $x$ & $x$ & 0 \\
\hline 5 & $\mathrm{EH}$ & $x$ & $x$ & $x$ & Yes & $x$ & Yes & Yes & $x$ & $x$ & $x$ & 4 \\
\hline 6 & EM & Yes & $x$ & $x$ & Yes & $x$ & Yes & Yes & $x$ & Yes & $x$ & 5 \\
\hline 7 & ET & $x$ & Yes & $x$ & $x$ & $x$ & Yes & Yes & $x$ & $x$ & $x$ & 5 \\
\hline 8 & $\mathrm{FG}$ & $x$ & $x$ & $x$ & $x$ & $x$ & Yes & Yes & $x$ & $x$ & $x$ & 7 \\
\hline 9 & HD & Yes & Yes & Yes & Yes & Yes & Yes & Yes & Yes & Yes & Yes & 12 \\
\hline 10 & $\mathrm{HN}$ & Yes & Yes & Yes & Yes & Yes & Yes & Yes & Yes & Yes & $x$ & 6 \\
\hline
\end{tabular}




\begin{tabular}{|c|c|c|c|c|c|c|c|c|c|c|c|c|}
\hline 11 & MS & Yes & Yes & Yes & Yes & $x$ & Yes & Yes & Yes & Yes & Yes & 6 \\
\hline 12 & MN & $\bar{x}$ & $x$ & $x$ & Yes & Yes & Yes & Yes & Yes & $x$ & Yes & 5 \\
\hline 13 & NJ1 & Yes & Yes & $x$ & $x$ & $x$ & Yes & Yes & $x$ & $x$ & $x$ & 10 \\
\hline 14 & NJ2 & $x$ & Yes & $x$ & Yes & $x$ & Yes & Yes & Yes & Yes & $x$ & 7 \\
\hline 15 & QS & Yes & Yes & Yes & Yes & $x$ & Yes & Yes & Yes & Yes & Yes & 8 \\
\hline 16 & RW & Yes & $x$ & Yes & Yes & Yes & Yes & Yes & Yes & $x$ & $x$ & 5 \\
\hline 17 & RH & Yes & Yes & Yes & Yes & Yes & Yes & Yes & $x$ & $x$ & Yes & 7 \\
\hline 18 & SD & Yes & Yes & Yes & Yes & $x$ & Yes & Yes & Yes & Yes & $x$ & 4 \\
\hline 19 & $\mathrm{ZN}$ & Yes & Yes & Yes & Yes & Yes & Yes & Yes & Yes & Yes & $x$ & 9 \\
\hline 20 & ZR & Yes & $x$ & Yes & $x$ & Yes & Yes & Yes & $x$ & Yes & $x$ & 6 \\
\hline & $\begin{array}{l}\text { COUNT } \\
=\end{array}$ & ${ }^{*} 13$ & *13 & 9 & *15 & 7 & *18 & *19 & 9 & 11 & 6 & $\begin{array}{l}\mu= \\
6.0\end{array}$ \\
\hline
\end{tabular}

Statistically, each participant wrote six steps in average $(\mu=6.0)$ in showing how

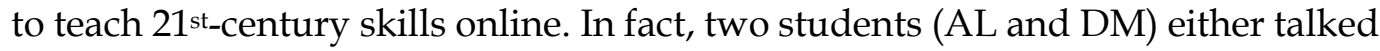
about theories or wrote a long description as opposed to showing steps. Conversely, HD illustrated 12 steps in incorporating $21^{\text {st-century skills into her }}$ lessons. Row 21 showed the frequency count $(\mathrm{COUNT}=)$ revealing that participants collectively focused on Lesson Preparation, Digital Set Up, Students' Background Knowledge, Lesson Introduction, and Development (see the asterisks *).

To begin, MS pensively observed that history will remember the powerful disruption that the Corona virus pandemic has brought to the world, and peoples' memories will be passed down to the coming generations. The impact it has had in the minds of one and all-pathological, psychological, and economical-and what it has been associated with-isolation, and halt of daily-life activities-is unpresented. The world needs time to get past this and determine what we, as educators and teachers, are supposed to do in relation to the community and our students.

In more depth, HN saw the importance of collaborating with parents, including goal-setting, learning outcomes, technologies for lesson delivery, parental support, deadlines for assignment submission, and answering parents' queries, to guarantee the success of distance learning. She said, "Communicating with parents via phone or social media platforms to clarify the purpose of the lesson will introduce to them its mechanism, and make them aware of the importance of this in the lives of girls in the primary stage". When planning lessons, HN pointed out that students' experience must be considered. The teacher needs to "make clear the values of great loyalty to the Kingdom of Saudi Arabia and conclude the lesson by directing students to thank God first for the existence of a rational government that cares about us, praying for all patients, and directing them to thank their families for offering this opportunity to meet online".

$\mathrm{EH}$ affirmed the need for student-centered instruction related to the COVID-19 pandemic, the symptoms of the disease and the ways of prevention. According to her, "at the outset, instruction would be achieved by briefly talking about the pandemic. That is to say, the teacher will explain in details to students the symptoms of the pandemic, and the ways of prevention by means of a video 
concerning the right way of washing hands in order to avoid contracting the disease, and also another video presentation on the importance of prevention against the Corona virus. Then, I would put forward the problem to students and try to elicit a number of solutions from them with substantiating evidence (using the skills of problem solving, critical thinking, and communication). After this, I would share with them the number of positive cases of the virus [in the world and the KSA], and I would ask the question: How can we minimize these figures? I would listen to their responses".

AL drew on a specific theoretical framework to frame a journal entry: Sternberg's (1988) theory of successful intelligence, which stated that intelligent human behaviour arose from a balance of analytical, creative and practical abilities thereby enabling people to be successful within given socio-cultural contexts. In this respect, she said, "The use of Sternberg's theory would help students to know themselves, identify their own strengths and weaknesses, rectify limitations, and utilize their own strengths in performance improvement. According to this theory, everyone needs the ability to think, analyze, and innovate in a scientific way in order to develop useful 21st-century skills".

EM, who is in favour of distance learning, described what she had done in an online class to teach elementary students with a special focus on 21st-century skills. She said, "At the outset, I made clear, through a video, the story of this disease. What is it? Where did it begin? What are the best ways to avoid it? And how can it be prevented? Here, I stimulated the students' thinking skills through viewing, clarifying the problem, and starting to think about solving the problem, thus combining and linking information and then analyzing and interpreting results".

As far as the lesson development is concerned, EM said, "I then displayed images, for example, ways of washing hands, mixing with people without caution, antiseptics, gloves, masks and the like. I then divided the students into groups and let them communicate and express their thoughts efficiently, using oral and written communication skills among themselves through their cell phones, because each student has her own cell phone.

For class activities, NJ1 said, "Divide the students in light of this topic into some categories (doctor, nurse, rescuer, vaccine manufacturer, teacher, official, security man). The following step is to listen to their ideas and what will be presented to reduce this pandemic and address it through own profession". ET said, "To achieve sharing and communication among students, giving them a word to search for its meaning on the internet to collect some information about it is considered a wise move. To achieve self-learning, it is significant to show some pictures that contain correct and wrong behaviours and ask pupils to critique them to achieve critical thinking. Certainly, technology here is the main tool and has been relied upon".

In addition, ZR said, "Interacting through technical media with people from other cultures benefits our pupils. Together they can identify how to reduce the 
incidence of disease, knowing what other countries are achieving, respecting the world's views on dealing with diseases, and accepting differences in cultures and new ideas to combat the disease".

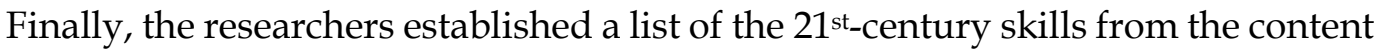
analysis that the study participants had aimed to teach their pupils. Accordingly, the top 11 skills were: collaboration \& communication, critical thinking, creative thinking, problem solving, information sharing, presentation skills, leadership skills \& responsibility taking, research skills, respecting others' ideas, digital skills, and self-directed learning skills.

\section{Discussion and Implications}

Recent research affirmed that the abrupt shift from traditional in-person, classbased learning to distance technology-based instruction has prompted teachers to adapt in their role as 21st-century educators (Colaneri et al., 2020; Ferdig, 2020; Hishan et al., 2020; Mulenga \& Marbán, 2020). The same seemed to hold in Saudi Arabia as far as the postgraduate elementary teachers in this sample frame are concerned. A critical finding was that despite the enormity of the challenges, participants expressed a sense of ample scope for personal and pedagogical transformation. An analysis of the collection of powerful extracts pulled from the overall data set revealed four common ideas around this finding.

First, threaded throughout the data was a collection of principles the participants wanted to instil in their students. They amounted to an esprit de core or common spirit that must be respected to sustain long-term morale, enthusiasm and eventual success in dealing with COVID-19. Participants wanted elementary students to embrace the idea that the country is depending on everyone's cooperation. Students have a duty to the nation, a responsibility to their community and to themselves, and with the latter meaning they must take responsibility for their own learning while learning to cooperate and value other's contributions.

Being the torchbearers responsible for the nation's future is a heady aspiration for elementary students at age 5 to 12, but it resonates with the core message of Vision 2030 (KSA, 2016, p. 72). Participants' esprit de core seems to reflect the sentiment that "we are each personally responsible for our own futures. As such, we will develop ourselves and will work to become independent and active members of society. ... We will remember our lifelong obligations to our families" (KSA, 2016, p. 72).

Mishrif and Alabduljabbar (2018) maintained that elementary education is very important because it helps pave the way for a nation's success. Elementary students must be taught how to bring out their inner talents to share responsibility for each other and their home country. The appearance of this idea in this exploratory study warranted further investigation especially on how pervasive it is among all Saudi elementary teachers, and whether they are in the graduate school or not. At first glance, it appeared that it might not be realistic for the study participants to expect their pupils to take on such a grave responsibility in shaping 
their nations' future considering their tender age. Others, nonetheless, thought this is reasonable. Abualrob (2019) claimed it is never too early to start learning 21st-century skills, which are essential for nation building. Mead (2016) also asserted that elementary education is a powerful predictor of a child's life outcomes and contributions.

Second, as would be expected, participants commented on technical issues wherein, when preparing their online COVID-19 lesson, they intended to orient themselves and learners to the digital learning site where future learning would take place (e.g., Zoom, Collaborate, etc.). In this concern, future research should explore whether other Saudi female elementary educators would feel obligated to ensure a well-run virtual classroom, or whether this was unique to this small sample frame. Several researchers have documented the technical-related challenges teachers have faced switching to online learning and advocated for preparedness (O'Brien et al., 2020; König et al., 2020). It is the instructor's responsibility to ensure that the learning environment operated well (König et al., 2020; Rapanta et al., 2020).

Some participants also tried to affirm for themselves that distance education is beneficial and that students can learn this way. Other studies have recognized similar concerns (Al-Roubaie \& Alaali, 2020; Khatun \& Saadat, 2020; Kovačević, 2020). Given that this shift to distance learning was immediate and imposed, it therefore made sense that some participants sought validation of its merit and tried to ease their misgivings. Lederman (2020) concurred that doubts about its efficacy are natural and widespread with most educators rapidly embracing it. Participants in this Arab-world study appeared to be following this trend.

Study participants (enrolled part-time in a master's degree program) averaged eight years of teaching experience and seemed to be receptive to distance learning. Other researchers have reported that more experienced teachers are most receptive (Lapada et al., 2020). Future studies could discern how receptive other Saudi female elementary educators are to online learning (with a focus on work experience differences), and whether they express doubts about its efficacy to help very young children learn. Results from such research could inform pre-service, postgraduate and in-service professional development initiatives.

Third, most participants commented on specific instructional strategies they would or had already used to teach an online COVID-19 lesson. Most of them indicated that before getting students to engage with the topic, they, as the teachers, would prepare and share (via PowerPoints and videos) background material on COVID-19. With this scaffolding, different instructional strategies were shared. Van Gompel (2019) observed that self-directed, active learning and experiential learning strategies are important. The development of studentcentered learning strategies in an unconventional learning environment such as an online platform will need to be further examined. University teacher-training programs, either at bachelors or masters degree level, should purposefully focus on these instructional strategies and how to implement them via distance 
education platforms. Since this paper placed focus on the teachers themselves, future investigations should be made through the lens of the pupils.

Several study participants specifically commented on the need to pay attention to evaluation strategies and to regularly communicate this aspect of the course with students. Per MS's comment, they favoured "student evaluation based on participation."In this way, we will need to understand the shift in the new assessment method, which is unconventional in Saudi Arabia, and tailor both preservice teacher teaching and in-service professional development to this methodological shift. Due to the pandemic, study participants were veering away from the traditional rote learning pedagogy (Basham et al., 2020; Jung 2020; Sekiyama, 2020) towards more student-centered, self-directed learning with authentic assessment strategies (i.e., students demonstrate what they are learning rather than just recall facts and information) and concerted efforts to communicate this active learner participation to students. EM commented that "I have kept my students informed... making clear the evaluation policy and its strategies."

Fourth, several participants made a point to say their approach to teaching had changed upon shifting to distance learning mode. EM explicitly said, "since this crisis, I have changed my teaching methods." Participants saw themselves as facilitators who actively ensured consensus building amongst learners, and reinforced the power of teamwork and collaborative, self-directed learning - in effect, student-centered learning (Van Gompel, 2019). With this pedagogical shift, many participants elaborated on changes in their pedagogy. Comments varied but included: (a) a deeper respect for different learning styles; (b) the merit of the problem-solving approach with substantiated evidence; (c) being mindful of questions posed to students using ones that made them think with the requirement that the teacher listen to their answers; and (d) ensuring students' chance to learn about themselves (strengths and weaknesses) and innovate. Further research should determine if the findings from this exploratory study hold true for the majority of Saudi elementary teachers who also had to shift pedagogical gears so rapidly. Further investigation, therefore, will need to show whether Saudi elementary educators were all open to such a pedagogical change and whether the Saudi female elementary teachers were skilfully shifting pedagogical approaches in such a short time frame.

Many study participants reiterated the importance of elementary students being able to learn 21st-century skills with the most frequently mentioned, including: critical thinking, problem solving, communicating, creative thinking, innovation, and analyzing (Abualrob, 2019; Stauffer, 2020; Van Gompel, 2019). Granted, part of the research design protocol specifically requested participants to ensure that elementary students can develop 21st-century skills while learning via distance education. One cannot assume safely that teachers outside the scope of this study will link this imperative with their efforts to teach using distance learning platforms. Thus, it would be needed to draw their attention explicitly to such an imperative shift. Without further investigations, it would be impossible to a certain extent to ascertain whether learning 21st-century skills is on the radar of 
Saudi female elementary educators other those who were in this postgraduate sample frame.

\section{Limitations}

First, this exploratory study was undertaken with only 20 female postgraduate students at one Saudi university. Future studies should draw from other Saudi universities across the nation and solicit data from male elementary teachers as well who comprise nearly half of Saudi educators teaching young children. Second, the study participants were either gainfully employed or seeking employment as elementary teachers. Future studies should focus on both years of work experience and employment status of the participants to determine if these variables would impact their thoughts about what is involved in preparing lessons for online learning that ensure elementary students' learning of 21stcentury skills. Third, there is a need for broader research using both qualitative and quantitative research designs to best represent and cross-check teachers' experiences in such situations.

\section{Conclusion}

Findings suggested that the COVID-19 pandemic has had a significant influence on and changed the educational process for these Saudi postgraduate students who were also gainfully employed or seeking positions as elementary educators. The results were very encouraging. That is, despite the pandemic and national lockdown, participants were empowered because the shift to online education enabled them to continue their pursuit of their postgraduate studies in elementary education. They could also apply what they had learned from the university program into their online teaching incorporating 21st-century skills for their pupils. The way they put pedagogical theories and teaching methodologies into practice would benefit the younger generations who possessed adequate digital skills. No doubt, their formative years have been indelibly shaped by a global pandemic that has changed the world. Nevertheless, their teachers have stepped up to the challenge taking on the mission of educating and equipping youngsters with new, most-needed skills to thrive in the future.

If other Saudi elementary teachers had also found a similar comfort level using online learning platforms to instil 21st-century skills, the future of elementary education in Saudi Arabia looked promising. Participants' comments were thought-provoking and optimistic, reflecting their openness to using alternative modes of learning that still meet the needs of elementary pupils. The study participants contributed an array of digital resources, teaching techniques, learning activities, and evaluation methods. Subsequently, a list of the 21stcentury skills that their pupils could acquire during the lesson has emerged, as a result. This research has offered the international audience deeper insights into the teaching practices of elementary school teachers in Saudi Arabia during the pandemic. 


\section{References}

Abualrob, M. (2019). Determinants of building 21st-century skills in Palestinian elementary schools. Higher Education Studies Journal, 9(2), 108-116. https:// doi.org/10.5539/hes.v9n2p108

Alaboudi, A., \& Alharbi, A. S. (2020). Impact of digital technology on Saudi students. International Journal of Information Technology. https://doi.org/10.1007/s41870-020-00451-7

Alazmy, W., Samarkandi, O., \& Williams, B. (2020). The history of emergency medical services response to mass casualty incidents in disasters, Saudi Arabia. Journal of Emergency Medicine, Trauma and Acute Care, 2020(1), 3012. https://doi.org/10.5339/jemtac.2020.3

Aldarhami, A., Bazaid, A. S., Althomali, O. W., \& Binsaleh, N. K. (2020). Public perceptions and commitment to social distancing during the COVID-19 pandemic: A national survey in Saudi Arabia. https:/ / www.preprints.org/manuscript/202005.0517/v1

Algaissi, A. A., Alharbi, N. K., Hassanain, M., \& Hashem, A. M. (2020). Preparedness and response to COVID-19 in Saudi Arabia: Building on MERS experience. Journal of Infection and Public Health, 13(6), 1-14. https://doi.org/10.1016/j.jiph.2020.04.016

Almutairi, S. M., Gutub, A. A. A., \& Al-Juaid, N. A. (2020). Motivating teachers to use information technology in educational process within Saudi Arabia. International Journal of Technology Enhanced Learning, 12(2), 200-217. https://doi.org/10.1504/IJTEL.2020.106286

Al-Roubaie, A., \& Alaali, M. (2020). The fourth industrial revolution: Challenges and opportunities for the MENA Region. In M. G. Leitch \& C. J. Rushton (Eds.), Joint European-US workshop on applications of invariance in computer vision (pp. 672-682). Springer.

Al Saidi, A. M. O., Nur, F. A., Al-Mandhari, A. S., El Rabbat, M., Hafeez, A., \& Abubakar, A. (2020). Decisive leadership is a necessity in the COVID-19 response. The Lancet, 396(10247), 295-298. https:/ / doi.org/10.1016/S0140-6736(20)31493-8

Alshammari, R. (2020). The current use of mobile devices among students and faculty in EFL teaching in a Saudi Arabian context. Turkish Online Journal of Educational Technology, 19(2), 34-51.

Alyami, H. S., Orabi, M. A., Aldhabbah, F. M., Alturki, H. N., Aburas, W. I., Alfayez, A. I., Alharbi; A., Almasuood; R. A., \& Alsuhaibani, N. A. (2020). Knowledge about COVID-19 and patients' beliefs about and use of herbal products during the COVID-19 pandemic: A cross-sectional study in Saudi Arabia. https://www.xmol.com/paper/1275880461310652416

Anderson, C. (2010). Presenting and evaluating qualitative research. American Journal of Pharmaceutical Education, 74(8). https://doi.org/10.5688/aj7408141

Armitage, R., \& Nellums, L. B. (2020). Considering inequalities in the school closure response to COVID-19. The Lancet Global Health, 8(5). https://doi.org/10.1016/S2214-109X(20)30116-9

Auger, K. A., Shah, S. S., Richardson, T., Hartley, D., Hall, M., Warniment, A., Timmons, K., Bosse, D., Ferris, S. A., Brady, P. W., Schondelmeyer, A. C., \& Thomson, J. E. (2020). Association between statewide school closure and COVID-19 incidence and mortality in the US. JAMA, 324(9), 859-870. https://doi.org/10.1001/jama.2020.14348

Basham, J. D., Han, K., Zhang, L., \& Yang, S. (2020). Considering the fourth industrial revolution in the preparation of learners with and without disabilities. In Careers for students with special educational needs: Perspectives on development and transitions from the Asia-Pacific region (pp. 31-48). Springer. 
Bayrakdar, S., \& Guveli, A. (2020). Inequalities in home learning and schools' provision of distance teaching during school closure of COVID-19 lockdown in the UK. Institute for Social and Economic Research Working Paper Series. https://www.iser.essex.ac.uk/research/publications/workingpapers/iser/2020-09.pdf

Burgess, S., \& Sievertsen, H. H. (2020). Schools, skills, and learning: The impact of COVID-19 on education. https://voxeu.org/article/impact-COVID-19-education

Campa, R. (2020). Fourth industrial revolution and emotional intelligence: A conceptual and scientometric analysis. Changing Societies \& Personalities, 4(1), 8-30. http://hdl.handle.net/10995/82236

Colaneri, M., Sacchi, P., Zuccaro, V., Biscarini, S., Sachs, M., Roda, S., 1 Chiara, T., Valsecchi, P., Piralla, A., Seminari, E., Matteo, A. S., Maiocchi, L., Pagnucco, L., Tirani, M., Baldanti, F., Mojoli, F., Perlini, F., Bruno, R., \& Di Matteo, A. (2020). Clinical characteristics of corona virus disease (COVID-19): Early findings from a teaching hospital in Pavia, North Italy. Eurosurveillance, 25(16). https://www.ncbi.nlm.nih.gov/pmc/articles/PMC7189652/

Corden, A., \& Sainsbury, R. (2006). Using verbatim quotations in reporting qualitative social research: Researchers' views. York, England: University of York, Social Policy Research

Unit. https://www.york.ac.uk/inst/spru/pubs/pdf/verbquotresearch.pdf

Douglas, M., Katikireddi, S. V., Taulbut, M., McKee, M., \& McCartney, G. (2020). Mitigating the wider health effects of COVID-19 pandemic response. https://doi.org/10.1136/bmj.m1557

Dudovskiy, J. (2016). The ultimate guide to writing a dissertation in business studies. Research Methodology. http://research-methodology.net/about-us/ebook/

Erlingsson, C., \& Brysiewics, P. (2017). A hands-on guide to doing content analysis. African $\begin{array}{llll}\text { Journal of Emergency } & \text { Medicine, } & \text { 7(3), } & \text { 93-99. }\end{array}$ https://doi.org/10.1016/j.afjem.2017.08.001

Esposito, S., \& Principi, N. (2020, May 13). School closure during the coronavirus disease 2019 (COVID-19) pandemic: An effective intervention at the global level?. JAMA Pediatrics, 174(10), 921-922. https://doi.org/10.1001/jamapediatrics.2020.1892

Ferdig, R. E., Baumgartner, E., Hartshorne, R., Kaplan-Rakowski, R., \& Mouza, C. (2020). Teaching, technology, and teacher education during the COVID-19 pandemic: Stories from the field. Association for the Advancement of Computing in Education. https://www.learntechlib.org/p/216903/

Gagnon, K., Young, B., Bachman, T., Longbottom, T., Severin, R., \& Walker, M. J. (2020). Doctor of physical therapy education in a hybrid learning environment: Reimagining the possibilities and navigating a "new normal". Physical Therapy and Rehabilitation Journal, 100(8), 1268-1277. https://doi.org/10.1093/ptj/pzaa096

Hackett, C., \& McClendon, D. (2017). Christians remain world's largest religious group, but they are declining in Europe. https://www.pewresearch.org/facttank/2017/04/05/christians-remain-worlds-largest-religious-group-but-theyare-declining-in-europe/

Hilppö, J., Rainio, A., Rajala, A., \& Lipponen, L. (2020). Children and the COVID-19 lockdown: From child perspectives to children's perspectives. Cultural Praxis, 20(6), 24-32.

Hishan, S. S., Ramakrishnan, S., Qureshi, M. I., Khan, N., \& Al-Kumaim, N. H. S. (2020). Pandemic thoughts, civil infrastructure and sustainable development: Five insights from COVID-19 across travel lenses. Journal of Talent Development and Excellence, 12(2), 1690-1696. 
Jung, J. (2020). The fourth industrial revolution, knowledge production and higher education in South Korea. Journal of Higher Education Policy and Management, 42(2), 134-156. https://doi.org/10.1080/1360080X.2019.1660047

Khatun, F., \& Saadat, S. Y. (2020). Fourth industrial revolution, technological advancement and youth employment: A South Asian perspective. South Asia Economic Journal, 21(1), 58-75. https:// doi.org/10.1177/1391561420914187
Kingdom of Saudi Arabia. (2016). Vision 2030 https://vision2030.gov.sa/sites/default/files/report/Saudi_Vision2030_EN_20 17.pdf

Kirklees Council. (n.d.). Involve: Analyzing and reporting qualitative data. https://www.kirklees.gov.uk/involve/document/AnalysingQualitativeData.p df

König, J., Jäger-Biela, D. J., \& Glutsch, N. (2020). Adapting to online teaching during COVID-19 school closure: Teacher education and teacher competence effects among early career teachers in Germany. European Journal of Teacher Education, 43(4), 608-622. https://doi.org/10.1080/02619768.2020.1809650

Kovačević, A. (2020). Creativity and innovation in educating engineers and product designers of the 21st century for the fourth industrial revolution. In Handbook of research on integrating industry 4.0 in business and manufacturing (pp. 568-586). IGI Global.

Lapada, A. A., Miguel, F. F., Roldan, R. D. A., \& Alam, Z. F. (2020). Teachers' Covid-19 awareness, distance learning education experiences and perceptions towards institutional readiness and challenges. International Journal of Learning, Teaching and Educational Research, 19(6), 127-144. https://doi.org/10.26803/ijlter.19.6.8

Lederman, D. (2020). Will shift to remote teaching be boon or bane for online learning? https://www.insidehighered.com/digital-learning/article/2020/03/18/mostteaching-going-remote-will-help-or-hurt-online-learning

Lee, J. (2020). Mental health effects of school closures during COVID-19. The Lancet: Child E Adolescent Health, 4(6). https://doi.org/10.1016/S2352-4642(20)30109-7

Lingard, L. (2019). Beyond the default colon: Effective use of quotes in qualitative research. Perspectives on Medical Education, 8(6), 360-364. https://doi.org/10.1007/s40037019-00550-7

Loima, J. (2020). Socio-educational policies and Covid-19: A case study on Finland and Sweden in spring 2020. International Journal of Education and Literacy Studies, 8(3), 59-75.

McGregor, S. L. T. (2018). Understanding and evaluating research. SAGE.

Mead, S. (2016). Don't forget the early elementary years. https://www.usnews.com/opinion/articles/2016-10-06/early-elementaryeducation-years-are-important-for-public-policy

Mishrif, A., \& Alabduljabbar, A. (2018). Quality of education and labour market in Saudi Arabia. In A. Mishrif \& Y. Al Balushi (Eds.), Economic diversification in the Gulf Region, Volume I (pp. 97-115). Palgrave Macmillan. https:/ / doi.org/10.1007/978981-10-5783-0_5

Mulenga, E. M., \& Marbán, J. M. (2020). Prospective teachers' online learning mathematics activities in the age of COVID-19: A cluster analysis approach. EURASIA Journal of Mathematics, Science and Technology Education, 16(9). https://doi.org/10.29333/ejmste/8345

Nana (2020, November 10). 21st century skills for kids \& rethinking how students learn. SKIDOS. https://skidos.com/blog/21st-century-skills-for-kids-students/

Obaid, R. (2019). Women teach young boys for the first time in Saudi public schools. https://www.arabnews.com/node/1548366/saudi-arabia 
O'Brien, W., Adamakis, M., O'Brien, N., Onofre, M., Martins, J., Dania, A., \& Costa, J. (2020). Implications for European Physical Education Teacher Education during the COVID-19 pandemic: A cross-institutional SWOT analysis. European Journal of Teacher Education, 43(4), 503-522. https:/ / doi.org/10.1080/02619768.2020.1823963

Poletti, M., \& Raballo, A. (2020). Letter to the editor: Evidence on school closure and children's social contact: Useful for corona virus disease (COVID-19)? Eurosurveillance, 25(17), 200-223. https://doi.org/10.2807/15607917.ES.2020.25.17.2000758

Rapanta, C., Botturi, L., Goodyear, P., Guàrdia, L., \& Koole, M. (2020). Online university teaching during and after the Covid-19 crisis: Refocusing teacher presence and learning activity. Postdigital Science and Education, 2, 923-945. https://doi.org/10.1007/s42438-020-00155-y

Samra, H., Li, A., Soh, B., \& Zain, M. A. (2020). Utilisation of hospital information systems for medical research in Saudi Arabia: A mixed-method exploration of the views of healthcare and IT professionals involved in hospital database management systems. Health Information Management Journal,49(2-3), 117-126. https:// doi.org/10.1177/1833358319847120

Sekiyama, T. (2020). The impact of the fourth industrial revolution on student mobility from the perspective of education economics. Creative Education, 11(4), 435-447. https://doi.org/10.4236/ce.2020.114031

Simply Learning Tuition \& Consultancy. (2021). 21st century skills for children. https://www.simplylearningtuition.co.uk/advice-for-parents/21st-centuryskills-for-children/

Sintema, E. J. (2020). E-learning and smart revision portal for Zambian primary and secondary school learners: A digitalized virtual classroom in the COVID-19 era and beyond. Aquademia, 4(2). https://doi.org/10.29333/aquademia/8253

Stauffer, B. (2020). Ultimate guide to teaching 21st-century skills in secondary schools. https://info.aeseducation.com/ultimate-guide-teach-21st-century-skills

Sternberg, R. J. (1988). The triarchic mind: A new theory of human intelligence. New York: Viking.

UNESCO Institute for Statistics. (2019). Primary education, teachers (\% female) - Saudi Arabia. The World Bank Data. https:// data.worldbank.org/indicator/SE.PRM.TCHR.FE.ZS?locations=SA

Van Gompel, K. (2019). Cultivating 21st-century skills: An exploratory case study of design thinking as a pedagogical strategy for elementary classrooms [Doctoral dissertation, Pepperdine University]. ProQuest Dissertations and Theses global.

Viner, R. M., Russell, S. J., Croker, H., Packer, J., Ward, J., Stansfield, \& Booy, R. (2020). School closure and management practices during corona virus outbreaks including COVID-19: A rapid systematic review. The Lancet: Child \& Adolescent Health, 4(5), 397-404. https:// doi.org/10.1016/S2352-4642(20)30095-X

Voskoglou, M. (2020). New challenges for education in the forthcoming era of the fourth industrial revolution. In Inclusive growth in the fourth industrial revolution (pp. 98117). IGI Global.

Walden University. (2020). What's the importance of early childhood education?. https://www.waldenu.edu/online-masters-programs/ms-in-early-childhoodstudies/resource/what-is-the-importance-of-early-childhood-education

Wang, G., Zhang, Y., Zhao, J., Zhang, J., \& Jiang, F. (2020). Mitigating the effects of home confinement on children during the COVID-19 outbreak. The Lancet, 395(10228), 945-947. https:/ / doi.org/10.1016/S0140-6736(20)30547-X 